\title{
Ecomorphology and diet reflect the spatial segregation between two Siluriformes species inhabiting a stream of the Bodoquena Plateau, in Central Brazil
}

\author{
Francisco Severo-Neto', Fabrício B. Teresa² \& Otávio Froehlich
}

1. Laboratório de Zoologia, Universidade Federal de Mato Grosso do Sul, 79070-900 Campo Grande, MS, Brazil. (netosevero@hotmail.com) 2. Universidade Estadual de Goiás, Unidade Universitária de Ciências Exatas e Tecnológicas, 75132-903 Anápolis, GO, Brazil.

\begin{abstract}
Pimelodella taenioptera Miranda Ribeiro, 1914 and Imparfinis schubarti (Gomes, 1956) are two of the most common fish species in Bodoquena Plateau streams, Paraguay basin. These species have benthic habits and subaquatical observations suggested that they present differentiation in their preference for mesohabitat types. Pimelodella taenioptera shows preference for slow waters, such as pools, while $I$. schubarti is associated to riffles. In this study we investigated if the known patterns of mesohabitat use of P. taenioptera and I. schubarti can be predict by their ecomorphological and trophic traits. We described the dietary habits and ecomorphological attributes of P. taenioptera and I. schubarti individuals, captured in the Parque Nacional da Serra da Bodoquena (PNSB), Mato Grosso do Sul state, central Brazil. Pimelodella taenioptera presented a more generalist diet, consuming a total of 23 different food items. Imparfinis schubarti have a diet based exclusively on aquatic insects. The ecomorphological analysis revealed that the species differed in relation to five morphological traits associated to habitat use ( $p<0.01)$. The results of this study reveal a clear functional dissimilarity between P. taenioptera and I. shubarti. The observed trophic and ecomorphological patterns are congruent with the known habitat use for these species and probably reflect the spatial and temporal variability on conditions and resources present in riffles and pools. Therefore, as expected, the morphological and feeding attributes represent predictive information related to mesohabitat use.
\end{abstract}

KEYWORDS. Pimelodella, Imparfinis, ecomorphogical traits, mesohabitats, trophic ecology.

\begin{abstract}
RESUMO. Ecomorfologia e dieta refletem a segregação entre duas espécies de Siluriformes que habitam um córrego do Planalto da Bodoquena, no Brasil Central. Pimelodella taenioptera Miranda Ribeiro, 1914 e Imparfinis schubarti (Gomes, 1956) estão entre as espécies de peixe mais comuns nos riachos do Planalto da Bodoquena, bacia do rio Paraguai. Estas espécies compartilham hábito bentônico, entretanto observações subaquáticas sugerem que estas espécies apresentam diferenças na preferência por tipos de mesohábitats. Pimelodella taenioptera apresenta preferência por habitats lênticos, tais como poços, enquanto I. schubarti é associado a corredeiras. Neste estudo, investigamos se os padrões conhecidos de uso de mesohábitats de P. taenioptera e I. schubarti predizem suas características ecomorfológicas e tróficas. Descrevemos os hábitos alimentares e os atributos ecomorfológicos de indivíduos de P. taenioptera e I. schubarti, capturados no Parque Nacional da Serra da Bodoquena (PNSB), Estado do Mato Grosso do Sul, Brasil Central. Pimelodella taenioptera apresentou dieta mais generalista, consumindo um total de 23 itens alimentares. Imparfinis schubarti apresentou dieta exclusivamente composta por insetos aquáticos. A dieta de P. taenioptera foi mais variável na estação chuvosa do que na estação seca $(\mathrm{p}=0,05)$ e foi significativamente mais variável do que a dieta de $I$. schubarti $(\mathrm{p}<0,01)$. A variabilidade na composição da dieta entre indivíduos de $I$. schubarti não diferiu entre as estações $(\mathrm{p}=0,48)$. As análises ecomorfológicas revelaram que as espécies diferiram em relação a cinco traços morfológicos associados ao uso do hábitat $(\mathrm{p}<0,01)$. Os resultados obtidos neste estudo revelam uma clara diferenciação funcional entre $P$. taenioptera e I. shubarti. Os padrões tróficos ecomorfológicos observados são compatíveis com o uso de habitat conhecido para essas espécies e, provavelmente, reflete a variabilidade espacial e temporal nas condições e recursos presentes em corredeiras e poços. Dessa forma, conforme esperado, os atributos morfológicos e tróficos representam informações com poder preditivo relacionadas ao uso de meso-hábitat.
\end{abstract}

PALAVRAS-CHAVE. Pimelodella, Imparfinis, traços ecomorfológicos, meso-hábitats, ecologia trófica.

Streams are complex environments represented by a mosaic of physical, chemical and biological conditions (Frissel et al., 1986). Geomorphological and hydrological characteristics of streams are important to determine environmental heterogeneity and habitat availability for aquatic biota (GORMAN \& KARR, 1978). Accumulated evidence indicates that fish distribution across habitats is not random; instead, the fish-habitat relationship is mediated by functional traits (PofF, 1997; Teresa \& CASATTI, 2012; PeAse et al., 2012). This biological determinism takes its roots in evidence of ecological and evolutionary processes that explain contemporary patterns of species distribution.

A number of studies have shown that morphological traits of fish correlate with ecological aspects of the species (CAsatti \& Castro, 2006; Oliveira et al., 2010). This relationship is the basis of ecomorphology (PEREs-NeTO, 1999), and it provides support for the use of morphology as a surrogate of functional traits (PEASE et al., 2012). For example, morphology has been associated with swimming performance, habitat use, reproductive behavior and foraging (WATSON \& BALON, 1984; WoOtTON, 1998).

According to the habitat filtering hypothesis, species occurring locally are those that present the traits needed to deal to environmental restrictions, or filters (Poff, 1997). Therefore, morphologically different species would be expected to occur in environmentally distinct habitats that are subject to the effects of different filters. In addition, ecomorphological differences between sympatric and phylogenetically related species would favor coexistence through differential use of resources (WоOтTоN, 1998).

An alternative way to analyze the use of habitat by different species is through details of their feeding habits. Species that feed on detritus would be more related to benthic habitats, as well as those that feed primarily on 
items that fall into the water, such as allochthonous insects and fruits which would be more related to the surface. In addition, the variation in feeding habits of fish can be partially attributed to changes in the volume of water and turbidity, as well as the input of allochthonous material within streams across seasons (PAYNE, 1986). Besides the predictive value of feeding habits on habitat use at microhabitat scale, some patterns may also be identified across broader scales. For example, some studies have suggested that riffles are usually associated with low spatial and temporal variability in food availability (ANGERMEIER \& Schlosser, 1989; Teresa \& Casatti, 2012), while pools have more variable alimentary items available (ANGermeier \& KarR, 1984; Berkman \& Rabeni, 1987). These aspects could be reflected in the trophic structure of the assemblages, as we could expect that pool-dwelling fish species would have a higher spatial and temporal variation in the diet than riffle-dwelling species.

This study was conducted in Bodoquena Plateau, Mato Grosso do Sul, an important area where the headwaters of the most important rivers draining into the Pantanal are located (BeHr, 2001). The fish fauna of this region is considered very particular, with several endemic forms and a high diversity when compared with other areas of the headwaters (WILLINK et al., 2000). Subaquatical observations in the region suggested that two morphologically similar catfish species, Pimelodella taenioptera Miranda Ribeiro, 1914 and Imparfinis schubarti (Gomes, 1956), have spatial segregation, with P. taenioptera occurring mainly in pools and I. schubarti being most commonly found in riffles. In view of this, our aim was to investigate if the ecomorphological and trophic patterns of $P$. taenioptera and $I$. schubarti corroborate the known patterns of mesohabitat use for these species, considering the influences of seasonality. More specifically, we asked 1) if the ecomorphology of P. taenioptera and I. schubarti is predictive of their spatial segregation and, if so, which ecomorphological attributes would best explain the differences between these species; 2 ) if the diet of $P$. taenioptera and I. schubarti is predictive of their spatial segregation, and 3) if the diet variability differs within and between species, reflecting the patterns of resources availability expected for the mesohabitats where the species are found. We expect to found differences in the ecomorphology, diet composition and diet variability between P. taenioptera and I. schubarti, with higher variation in the diet among individuals of the pool-dwelling species, $P$. taenioptera. In relation to seasonality, we expect differences in the diet composition and diet variability between dry and rainy seasons for $P$. taenioptera, but not for I schubarti, as the former lives in a more spatially and temporally variable mesohabitat.

\section{MATERIAL AND METHODS}

Study area. The study was carried out in the Salobrinha stream located in the Parque Nacional da Serra da Bodoquena (PNSB), state of Mato Grosso do Sul, Central Brazil (Fig. 1). The park is located in the municipalities of Bonito, Bodoquena, Jardim and Porto Murtinho, in the south central part of Mato Grosso do Sul $\left(21^{\circ} 08^{\prime} 02^{\prime \prime}\right.$ to $20^{\circ} 38^{\prime} 26^{\prime \prime}$ 'S and $56^{\circ} 48^{\prime} 31^{\prime \prime}$ to $56^{\circ} 44^{\prime} 28^{\prime \prime} \mathrm{W}$ ), at the edge of the Pantanal of Nabileque, which is one of the priority areas for conservation of the biodiversity (MMA, 2002). The study site is located in the final stretch of Salobrinha stream, which flows through the PNSB area, where the vegetation is composed mostly of preserved semi-deciduous forest (DAMASCENo JR. et al., 2000).

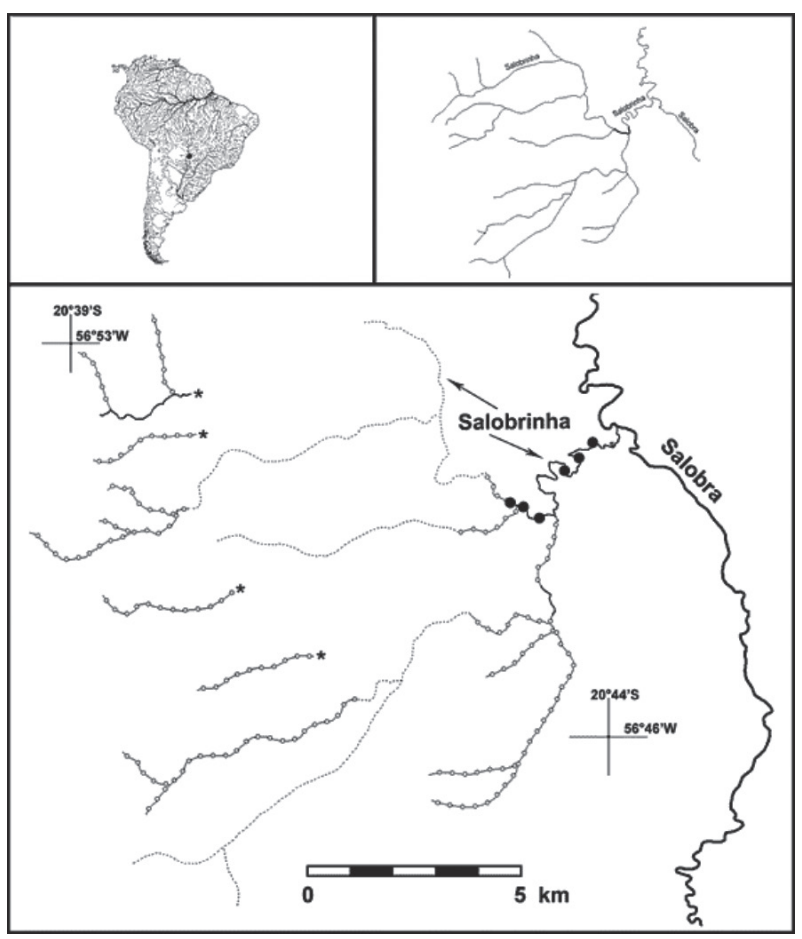

Fig. 1. Maps of the study area (Bodoquena, state of Mato Grosso do Sul, Brazil). On the main map, bottom lines with white circles represent intermittent stretches, dotted lines represent stretches with very ephemeral flow (only flowing during rain), and solid lines show the perennial stretches. Asterisks are sinks. Black circles are sampled sites.

Data sampling. Fish were collected at six sites in the Salobrinha stream, using electrofishing during daytime in the dry (July 2006) and rainy (March 2007) seasons. Specimens were fixed in formalin 10\%, and in the laboratory, they were washed, identified and transferred to alcohol $70 \%$.

Feeding. Feeding habits of the species were examined according to analysis of stomach contents from $P$. taenioptera individuals $(\mathrm{n}=200)$ and $I$. schubarti individuals $(n=60)$. Fragments of leaves, fruits or other parts of higher plants were classified as plant matter, while insects or other invertebrates were identified to the lowest taxonomic level possible with the help of specialized literature (Borror \& DeLong, 1988; Costa et al., 2006). Once identified, the items were described as being allochthonous or autochthonous. The volume of items was calculated by the volumetric method (HysLOP, 
1980), compressing the material with glass slides to a height of $1 \mathrm{~mm}$ on a plate in millimeters (HeLlawell \& ABEL, 1971) and then converting the value to volume (1 $\left.\mathrm{mm}^{3}=0.001 \mathrm{ml}\right)$.

Food items were grouped into broad food categories and then grouped according to their origin. Allochthonous resources included terrestrial insects (TIN), terrestrial invertebrates (TIV) (invertebrates other than insects) and terrestrial plants (TPL). Autochthonous resources included aquatic insects (AIN), aquatic invertebrates (AIV), fish (FIS) and algae (ALG). Detritus and sediment (DET) were considered of mixed origin.

Ecomorphology. For the analysis of ecomorphology, 15 morphological measures were taken from 38 individuals of I. schubarti and 50 individuals of P. taenioptera. Only adults were used to avoid allometric changes during ontogeny (GATZ, 1979a). The measures were obtained from GATZ (1979a), WATSON \& BALON (1984), WinEMILLER (1991) and PoulLLy et al. (2003), and they were taken with the aid of a digital caliper with $0.01 \mathrm{~mm}$ accuracy. Fins areas were taken in $\mathrm{mm}^{2}$ from contour drawn on graph paper. Measurements were then applied to 12 ecomorphological traits (Tab. I) that represent aspects of habitat use and trophic ecology (CASATti \& CAStro, 2006; Oliveira et al., 2010). Voucher specimens of $P$. taenioptera and $I$. schubarti were deposited in the Zoological Collection of the Universidade Federal de Mato Grosso do Sul (ZUFMSPIS 2100, ZUFMS-PIS 2101).

Data analysis. To identify multivariate patterns in the feeding of the species, an exploratory ordination technique (NMDS - nonmetric multidimensional scaling analysis) was employed using the volume data for each food item. This analysis was followed by ANOSIM using the Bray-Curtis dissimilarity coefficient to test the null hypothesis that no differences exist in the diet between and within species across seasons (ClARKE \& Gorley, 2006). In order to evaluate the between- and within-species diet variability, we calculated the multivariate dispersion in the diet of individuals by using the 'betadisper' function in the Vegan library in R. We compared the variability of the diet between species by pooling data from different seasons and between seasons within each species using the permutation test ('permutest' function).

Tab. I. Attributes used in the ecomorphological analysis with the corresponding measures taken and resulting ecological explanation.

\begin{tabular}{lrr}
\hline Ecomorphological attribute & Measures taken & Ecological explanation \\
\hline Compression Index (CI) & Body height divided by width & $\begin{array}{l}\text { Higher values indicate laterally compressed fish } \\
\text { that are inhabitants of slower waters (GATZ, 1979a) }\end{array}$
\end{tabular}

Index of ventral flattening (IVA)

Relative height of the body (RHB)

Relative length of caudal peduncle (RLCP)

Compression index of caudal peduncle (CICP)

Relative area of pectoral fin (RaPF)

Configuration of pectoral fin (CPF)

Relative area of caudal fin (RaCF)

Configuration of the caudal fin (CCF)

Relative length of the head (RLH)

Relative width of the mouth (RWM)

Relative height of the mouth (RHM)
Height of the body below the imaginary midline divided by height

Body height divided by standard length

Length of caudal peduncle divided by the standard length

Height of caudal peduncle divided by its width

Area of pectoral fin divided by body surface area

Ratio between length and width of pectoral fin

Caudal fin area divided by body area

Ratio of the square of the height of the caudal fin by its area

Head length divided by standard length

Mouth width divided by standard length

Height of the mouth divided by standard length
Lower values represent inhabitants of fast waters, allowing benthic individuals to maintain their position at the bottom without swimming (HoRA, 1930)

Inversely related to the speed of the animal and directly related to its ability to make vertical spins (GATZ, 1979a)

Long peduncles indicate good swimmers with good resistance to sites with higher turbulence (WATSON \& BALON, 1984)

More compressed peduncles indicate fish with lower speed (GATZ, 1979b)

High values are found in slower individuals who use fins for breaking and maneuvers, or in individuals who inhabit waters with greater flow, using the fins as current deflectors in order to remain close to the bottom (WATSON \& BALON, 1984)

High values are common to fish that travel long distances (MAHON, 1984)

Caudal fins with larger relative areas are important for acceleration (WEBB, 1977)

High values indicate active and continuous swimmers (GATZ, 1979a)

Relative to the size of prey consumed. High values may indicate fish that feed on relatively larger prey (GATZ, 1979a).

Relative to the size of prey consumed. High values may indicate fish that feed on relatively larger prey (GATZ, 1979a).

Relative to the size of prey consumed. High values may indicate fish that feed on relatively larger prey (GATZ, 1979a) 
We described ecomorphological variation within and between species through the principal component analysis (PCA) on a correlation matrix of ecomorphological traits. Significant PCA axes were identified by the broken-stick model (JACKSON, 1993). Complementarily, ecomorphological differences between species were tested by multivariate analysis of variance (MANOVA) and the Pillai-Trace statistic.

\section{RESULTS}

Feeding. From the total of individuals analyzed, $43 \%$ and $45 \%$ of P. taenioptera and I. schubarti individuals contained some alimentary item in the stomach, respectively. A total of 23 different food items were found in the stomachs of P. taenioptera (Tab. II). Autochthonous items had volume corresponding to $89 \%$ of the diet. The allochthonous material consisted of adult insects (Curculionidae, Eumastacidae, Blattodea), immature insects (Lepidoptera), and plant matter. During the rainy season, a decrease was noted in the frequency of insects and an increased consumption of fish scales and plant matter (Tab. II). Imparfinis schubarti have a diet based on nine food items, all represented by aquatic insects (Tab. II; Fig. 2), with a predominance of Trichoptera (Tab. I).

Ordination analysis with NMDS revealed no tendency toward segregation between species or seasons (ANOSIM, p>0.43) (Fig. 2). The evaluation of the multivariate dispersion of diet between species revealed that the diet of $P$. taenioptera was significantly more variable than that of I. schubarti $(\mathrm{p}<0.01)$. The evaluation of within-species diet variability showed that $P$. taenioptera individuals exhibited a higher variation in the diet in the rainy season than the dry season $(\mathrm{p}=0.05)$. However, the variability in diet composition among individuals of $I$. schubarti did not differ between dry and rainy seasons $(\mathrm{p}=0.48)$.

Ecomorphology. The first two axes of the PCA explained $54 \%$ of the variance in the ecomorphological data (Fig. 3), with axis 1 accounting for $39.8 \%$ of the variation. The first axis segregated the two species, and it was influenced by compression index (CI), relative height of the body (RHB), compression index of the caudal peduncle (CIPC), relative area of pectoral fin (RaPF) and relative area of caudal fin $(\mathrm{RaCF})$ (eigenvectors $=0.80,0.81,0.73,-0.91$, -0.83 respectively; Fig. 3 ). The second axis represented intraspecific variation in both species, and it was influenced by index of ventral flattening and relative length of the head. Only axis 1 had broken-stick eigenvalues significantly larger than random. The statistical test showed significant difference between the ecomorphological attributes of both species $(\mathrm{Gl}=1, \mathrm{~F}=157, \mathrm{p}<0.01)$.

Tab. II. Volume (\%) of consumed items by P. taenioptera Miranda Ribeiro, 2014 and I. schubarti (Gomes, 1956) in the Salobrinha stream, Mato Grosso do Sul, Brazil, in dry and rainy seasons.

\begin{tabular}{|c|c|c|c|c|}
\hline \multirow{2}{*}{ Feeding item } & \multicolumn{2}{|c|}{ Pimelodella taenioptera } & \multicolumn{2}{|c|}{ Imparfinis schubarti } \\
\hline & Dry & Rainy & Dry & Rainy \\
\hline \multicolumn{5}{|l|}{ Autochthonous items } \\
\hline Coleoptera, Elmidae & 19 & 10 & 13 & 16 \\
\hline Coleoptera, Psephenidae & 7.7 & 2.5 & 7.4 & - \\
\hline Diptera, Simuliidae & - & - & 26 & - \\
\hline Diptera, Chironomidae & 1.65 & - & - & 0.7 \\
\hline Ephemeroptera & - & - & 2.5 & - \\
\hline Ephemeroptera, Leptophlebiidae & 20 & 32 & 2.5 & 18 \\
\hline Hemiptera, Gerridae & - & 1 & - & - \\
\hline Hemiptera, Naucoridae & - & 2 & - & - \\
\hline Megaloptera, Corydalidae & - & 4 & - & - \\
\hline Odonata & 2.4 & 0.8 & - & - \\
\hline Odonata, Lestidae & 0.8 & - & - & - \\
\hline Plecoptera, Perlidae & - & - & 4.3 & - \\
\hline Trichoptera & 9 & 3 & 1.2 & - \\
\hline Trichoptera, Calamoceratidae & 0.8 & - & - & 11 \\
\hline Trichoptera, Hydropsychidae & 18 & 10 & 43 & 38 \\
\hline \multicolumn{5}{|l|}{ Allochthonous items } \\
\hline Blattodea & 0.8 & - & - & - \\
\hline Coleoptera & 2 & - & - & - \\
\hline Coleoptera, Curculionidae & 0.5 & 6 & - & - \\
\hline Hymenoptera,Formicidae & 0.8 & - & - & - \\
\hline Lepidoptera & - & 0.5 & - & 16 \\
\hline Orthoptera, Eumastacidae & 12 & - & - & - \\
\hline Scales & 28 & 6 & - & - \\
\hline Plant matter & 4 & 18 & - & - \\
\hline \multicolumn{5}{|l|}{ Mixed origin } \\
\hline Debris & - & - & - & 10 \\
\hline
\end{tabular}




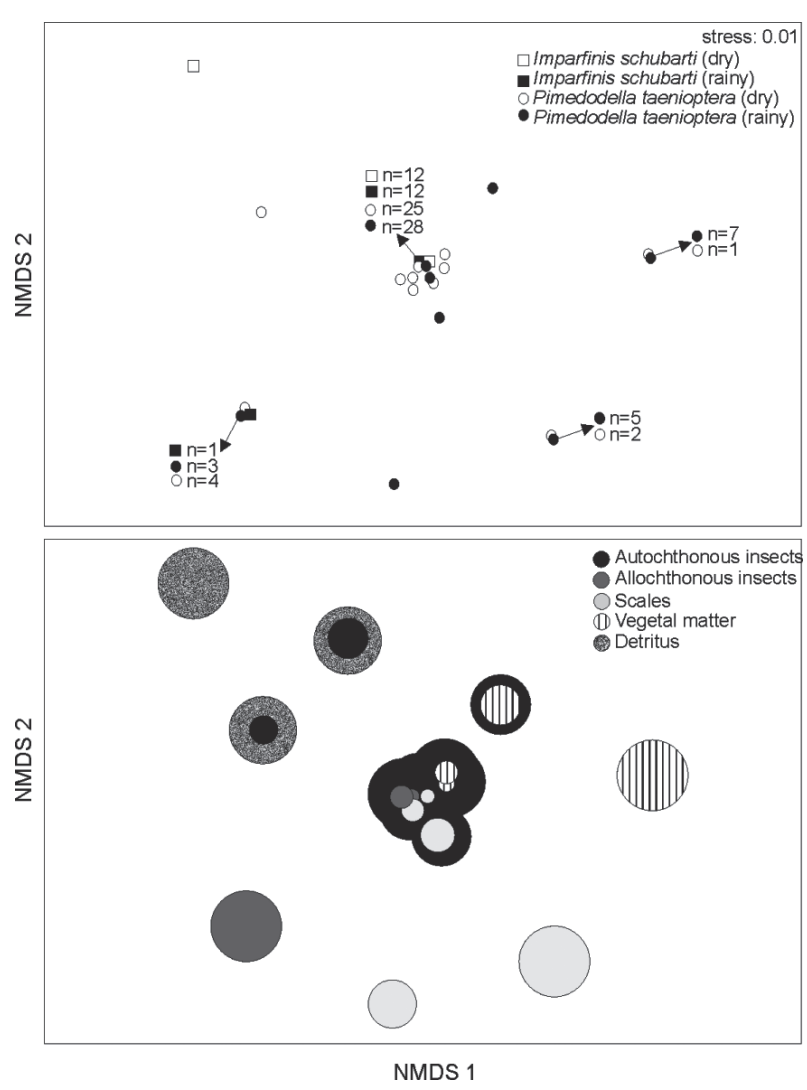

Fig. 2. Bi-dimensional projection of the axes resulting from Non-Metric Multidimensional Scaling analysis (NMDS), showing the ordination of individuals based on the grouped food items consumed (above). The importance of each food item category is expressed by the size of the bubble.

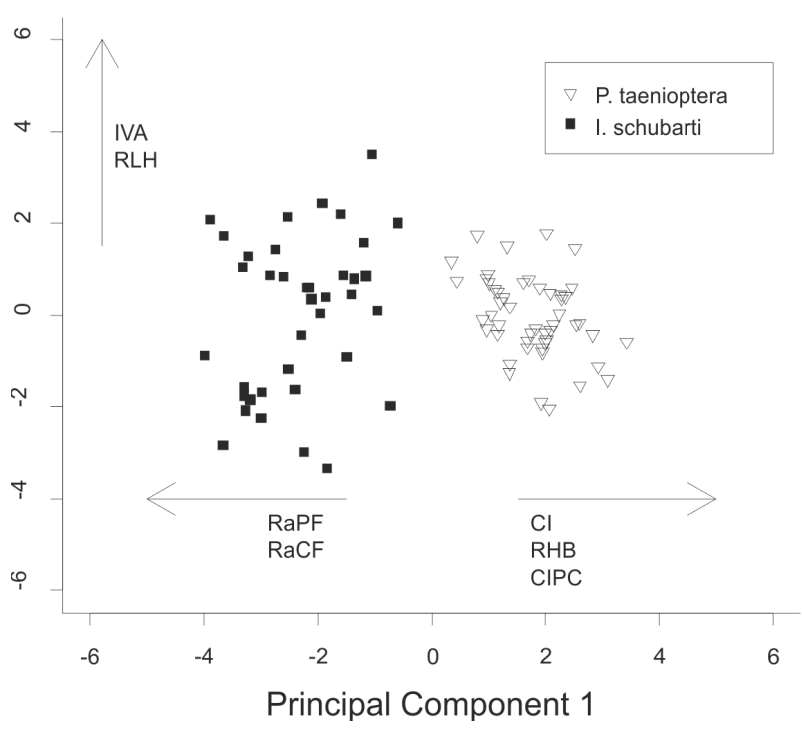

Fig. 3. Dispersion of the scores of the first two PCA axes, calculated with the correlation matrix of 12 ecomorphological attributes. The attributes that most influenced this distribution are shown: IVA, Index of ventral flattening; RLH, Relative length of the head; RaPF, Relative area of pectoral fin; RaCF, Relative area of caudal fin; CI, Compression index; RHB, Relative height of the body; CIPC, Compression index of caudal fin.

\section{DISCUSSION}

Knowledge about functional traits exhibited by species in relation to environmental gradients is a basic premise for prediction of species distributions across environmental gradients. In the present study, we described two important groups of functional traits, specifically, diet and ecomorphology, for two representative stream species in the Paraguay basin system. Previously subaquatic observations suggested that the studied species presents spatial segregation, with Pimelodella taenioptera occurring preferentially in pools, while I. schubarti is associated with riffles. The results of the present study provided support for this pattern and confirm the predictive value of diet and ecomorphology to infer habitat use.

Pimelodella taenioptera had a generalist diet, with the highest frequencies reported for aquatic insects. Terrestrial insects, fish scales and plant material supplemented the diet of this species. It is speculated that scales were captured through substrate since no remnants of fish intake in the analyzed stomach were observed, differing from Pimelodella pappenheimi Ahl, 1925 of Atlantic forest which, in addition to insects, also eats fish (ARANHA et al., 1998). A diet generalist, as exhibited by P. taenioptera, is compatible with pool-dwelling species which face low current velocity and often rich food resources (ANGERMEIER \& KARR, 1983; BÜRHNHEIM, 2002).

The consumption of plant matter registered in this study has already been reported for Pimelodella species (Viana et al., 2006; Rondineli et al., 2011). However, it is important to note that the largest amount of plant material was consumed in the rainy season. The increased frequency of this item in the feeding of $P$. taenioptera during rainy season is probably a response to a reduction in density of aquatic insects, which are eventually washed away by floods, as ascertained by Righi-CAVALLARO et al. (2010). Alternatively, plant material increases during the rainy season by the input of plant debris washed into the stream, increasing the availability of this resource and, at the same time, contributing to the increase of variability in the diet of this species during that season. These results are congruent with the temporally variable resources availability reported for pools (ANGERMEIER \& KARR, 1983). The opposite patterns have been suggested for riffles, whose environmental conditions and resource availability would be less variable than found in pools (Teresa \& Casatti, 2012).

The diet of Imparfinis schubarti consisted exclusively of autochthonous items, differing from the findings of MAzzoni et al. (2010) who studied a stream from the upper Tocantins basin (west central Brazil) and especially identified insects of allochthonous origin in the diet of Imparfinis borodini Mees \& Cala, 1989 and Imparfinis cf. schubarti. However, other studies focusing on other species of Imparfinis, as well as I. schubarti, have confirmed the results reported here (FERREIRA \& CASATTI, 2006; SILVA et al., 2012). In contrast to the patterns observed 
for $P$. taenioptera, the less variable and strictly insectivorous diet exhibited by the studied riffle-dwelling species corroborates previous findings that have highlighted the dominance of insectivorous species with more specialized habitats in riffles (CASATtI \& CASTRO, 1998; TERESA \& CASATTI, 2012). The fast water velocity and the limited availability of food items present in riffles (ANGERMEIER \& SCHLOSSER, 1989) are restrictive conditions which, according to TERESA \& CASATTI (2012), are successfully explored by two dominant functional groups: benthicgrazers-periphytivorous species, as represented mainly by loricariid species, and benthic-speculators-insectivorous fish, as represented by heptapterid species. Our results are congruent with this generalization, as I. schubarti may be considered a typical species of the latter group.

No marked differences were seen in the diet between species. This is evident when food items are grouped into broader food categories. In this case, the diet of Imparfinis schubarti is a subset of the Pimelodella taenioptera diet, with both showing a diet composed mainly of insects. However, the diet of $P$. taenioptera includes items not represented in the diet of I. schubarti, such as plant matter, allochthonous insects and scales. In a more detailed view, the main differences between the species were related to the frequency of consumption of certain insect orders. Imparfinis schubarti had a diet with fewer orders of insects and with greater participation, both in frequency and volume, of immature stages of Hydropsychidae (Trichoptera). Furthermore, the occurrence of Simuliidae, but only in the diet of I. schubarti, is also an indication of the use of riffles because these insects are immature forms of flies typical of fast waters (WARD, 1992). The highest consumption frequencies in the diet of $P$. taenioptera were, in decreasing order, the insect families Leptophlebiidae (Ephemeroptera), Elmidae (Coleoptera), Chironomidae (Diptera) and Hydropsychidae (Trichoptera). According to Righi-Cavallaro et al. (2010), these four families of insects are the most abundant in the community of insects found in the Salobrinha stream, even though chironomids suffer a drastic numerical drop during the rainy season. This reinforces $P$. taenioptera as an opportunist species, possibly feeding on the most common items available.

Based on the ecomorphological aspects, it was possible to differentiate the two species with respect to attributes related to swimming speed and acceleration. The three attributes related to Pimelodella taenioptera are compatible with living in pools (Oliveira et al., 2010) and indicate lower swimming speed when compared to other species of catfish. Imparfinis schubarti had larger pectoral and caudal fins, traits which are typical configurations of the morphology of species associated with fast-flowing habitats (WATSON \& BALON, 1984), contributing to the success of this species in riffles.

The present study revealed that, despite their close phylogenetic relationship, there is a clear functional dissimilarity between Pimelodella taenioptera and Imparfinis schubarti. These patterns are congruent with the habitat use known for these species and, probably reflect the spatial and temporal variability on conditions and resources present in riffles and pools. Therefore, as expected, the morphological and feeding attributes represent predictive information related to mesohabitat use.

Acknowledgements. The authors are grateful to many people who helped during data collection; to Gustavo Graciolli (UFMS) for his assistance in the identification of insects; to Raul Costa Pereira for his cooperation in various stages of the manuscript; to Conselho Nacional de Desenvolvimento Científico e Tecnológico - CNPq (Proc $\mathrm{n}^{\circ}$ 472113/2004-6) and Coordenação de Aperfeiçoamento de Pessoal de Nível Superior - CAPES for financial support.

\section{REFERENCES}

Angermeier, P. L. \& Karr, J. R. 1984. Relationships between woody debris and fish habitat in a small warm water stream. Transactions of the American Fisheries Society 113:716-726.

Angermeier, P. L. \& Schlosser, I. J. 1989. Species-area relationship for stream fishes. Ecology 70(5):1450-1462.

Aranha, J. M.; Takeuti, D. F. \& Yoshimura, T. M. 1998. Habitat use and food partitioning of fishes in a coastal stream of Atlantic Forest, Brazil. Revista de Biología Tropical 46(4):951-960.

BEHR, M. F. 2001. Serra da Bodoquena: História, cultura, natureza. Campo Grande, Ed. Free. 152p.

Berkman, H. E. \& Rabeni, C. F. 1987. Effect of siltation on stream fish communities. Enviromental Biology of Fishes 18(4):285-294.

Borror, D. J. \& Delong, D. M. 1988. Introdução ao estudo dos insetos. São Paulo, Edgard Blücher. 635p.

BüRhNHEIM, C. M. 2002. Heterogeneidade de habitats: rasos x fundos em assembléias de peixes de igarapés de terra firme na Amazônia Central. Revista Brasileira de Zoologia 19:889-905.

Casatti, L. \& CAstro, R. M. C. 1998. A fish community of the São Francisco River headwaters riffles, southeastern Brazil. Ichthyological Exploration of Freshwaters 9(3):229-242.

2006. Testing the ecomorphological hypothesis in a headwater riffles fish assemblage of the rio São Francisco, southeastern Brazil. Neotropical Ichthyology 4(2):203-214.

Clarke, K. R. \& Gorley, R. N. 2006. PRIMER v6: user manual/ tutorial. Plymouth, PRIMER-E. 192p.

Costa, C.; Ide, S. \& SimonkA, C. E. 2006. Insetos imaturos. Ribeirão Preto, Holos. 249p.

Damasceno-JR, G. A.; Nakajima, J. N. \& Rezende, U. M. 2000. Levantamento florístico das cabeceiras dos rios Negro, Aquidauana, Taquari, Miranda no Pantanal, Mato Grosso do Sul, Brasil.. In: Willink, P.W.; Chernoff, B.; Alonso, L.; Montambault, J. R. \& Lourival, R. eds. RAP Bulletin of Biological Assesment, 18: Uma Avaliação Biológica dos Ecossistemas Aquáticos do Pantanal, Mato Grosso do Sul, Brasil. Washington, Conservation International, p. $152-162$.

Ferreira, C. P. \& CASATti, L. 2006. Integridade biótica de um córrego na bacia do Alto Rio Paraná avaliada por meio da comunidade de peixes. Biota Neotropica 6:1-25.

Frissell, C. A.; Liss, W. J.; Warren, C. E. \& Hurley, M. D. 1986. A hierarchical framework for stream habitat classification: viewing streams in a watershed context. Enviromental Management 10(2):199-214.

Gatz, A. J. 1979a. Community organization in fishes as indicated by morphological features. Ecology 60(4):711-718.

. 1979b. Ecological morphology of freshwater stream fishes. Tulane Studies in Zoology and Botany 21(2):91-124.

Gorman, O. T. \& KarR, J. R. 1978. Habitat structure and stream fish communities. Ecology 59(3):507-515.

Hellawell, J. M. \& ABel, R. 1971. A rapid volumetric method for the analysis of the food of fishes. Journal of Fish Biology 3:29-37.

Hora, S. L. 1930. Ecology, bionomics and evolution of the torrential fauna, with special reference to the organs of attachment. Philosophical Transactions of the Royal Society of London 28:171-282. 
Hyslop, E. J. 1980. Stomach contents analysis: a review of methods and their application. Journal of Fish Biology 17:411-429.

JACKSON, D. A. 1993. Stopping rules in principal components analysis: a comparison of heuristical and statistical approaches. Ecology 74:2204-2214

Maноn, R. 1984. Divergent structure of fish taxocenes of north temperate streams. Canadian Journal of Fish. Aquatic Sciences 41:330-350.

Mazzoni, R.; Moraes, M.; Rezende, C. F. \& Miranda, J. C. 2010. Alimentação e padrões ecomorfológicos das espécies de peixes de riacho do alto Tocantins, Goiás, Brasil. Iheringia, Série Zoologia 100(2):162-168.

MMA - Ministério Do Meio AmBiente. 2002. Avaliação e identificação de áreas e ações prioritárias para a conservação, utilização sustentável e repartição dos benefícios da biodiversidade nos biomas brasileiros. Brasília, MMA/SBF. Available at <http://www. mma.gov.br/estruturas/chm/_arquivos/biodivbr.pdf $>$. Acessed on 27 November 2013.

Oliveira, E. F.; Goulart, E.; Breda, L.; Minte-Vera, C. V.; Paiva, L. R. S. \& Vismara, M. R. 2010. Ecomorphological patterns of the fish assemblage in a tropical floodplain: effects of trophic, spatial and phylogenetic structures. Neotropical Ichthyology 8(3):569-586.

PAYNE, A. I. 1986. The ecology of tropical lakes and rivers. New York, John Wiley and Sons. 301p.

Pease, A. A.; González-Díaz, A. A.; Rodiles-Hernández, R. \& Winemiller, K. O. 2012. Functional diversity and trait-environment relationships of stream fish assemblages in a large tropical catchment. Freshwater Biology 57(5):1060-1075.

Peres-Neto, P. R. 1999. Alguns métodos e estudos em ecomorfologia de peixes de riachos. In: Caramaschi, E. P.; Mazzoni, R. \& Peres-Neto, P. R. eds. Ecologia de Peixes de Riachos. vol. VI. Rio de Janeiro, Oecologia Brasiliensis, p. 209-236.

Poff, N. L. R. 1997. Landscape filters and species trait: towards mechanistic understanding and prediction in stream ecology. Journal of the North American Benthological Society 16(2):391-409.

Pouilly, M.; Lino, F.; Bretenoux, J. G. \& Rosales, C. 2003. Dietarymorphological relationships in a fish assemblage of the Bolivian Amazonian floodplain. Journal of Fish Biology 62(6):1137-1158.

Righi-Cavallaro, K. O.; Roche, K. F.; Froehlich, O. \& Cavallaro, M. R. 2010. Structure of macroinvertebrate communities in riffles of a Neotropical karst stream in the wet and dry seasons. Acta Limnologica Brasiliensia 22(3):306-316.
Rondineli, G.; Gomiero, L. M.; Carmassi, A. L. \& Braga, F. M. S. 2011. Diet of fishes in Passa Cinco stream, Corumbataí River sub-basin, São Paulo state, Brazil. Brazilian Journal of Biology 71(1):157-167.

Silva, J. C.; Delariva, R. L. \& Bonato, K. O. 2012. Food-resource partitioning among fish species from a first-order stream in northwestern Paraná, Brazil. Neotropical Ichthyology 10(2):389-399.

TERESA, F. B. \& CASATTI, L. 2012. Influence of forest cover and mesohabitat types on functional and taxonomic diversity of fish communities in Neotropical lowland streams. Ecology of Freshwater Fish 21:433442.

Viana, L. F.; Santos, S. L. \& Lima-JunioR, S. E. 2006. Variação sazonal na alimentação de Pimelodella cf. gracilis (Osteichthyes, Siluriformes, Pimelodidae) no rio Amambai, Estado de Mato Grosso do Sul. Acta Scientiarum, Biological Sciences 28(2):123-128.

WARD, J. V. 1992. Aquatic insect ecology: biology and habitat. Toronto, John Wiley and Sons. 438p.

WAtson, D. J. \& BALON, E. K. 1984. Ecomorphological analysis of fish taxocenes in rainforest streams of northern Borneo. Journal of Fish Biology 25(3):371-384.

Webi, P. W. 1977. Effects of median-fin amputation on fast-start performance of rainbow trout (Salmo gairdneri). Journal of Experimental Biology 68:123-135.

Willink, P. W.; Froehlich, O.; Machado-Allison, A.; Menezes, N. A.; Oyakama, O. T.; Catella, A. C.; Chernoff, B.; Lima, F. C. T.; Toledo Piza, M.; Ortega, H.; Zanata, A. M. \& Barriga, R. 2000. Diversidade, Distribuição, e Habitats Críticos dos Peixes dos Rios: Negro, Negrinho, Taboco, Taquari e Miranda, e sua importância para Conservação e Desenvolvimento Sustentável do Pantanal, Mato Grosso do Sul, Brasil. In: Willink, P. W.; Chernoff, B.; Alonso, L.; Montambault, J. R. \& Lourival, R. eds. RAP Bulletin of Biological Assesment, 18: Uma Avaliação Biológica dos Ecossistemas Aquáticos do Pantanal, Mato Grosso do Sul, Brasil. Washington, Conservation International, p. 63-81.

WinemilleR, K. O. 1991. Ecomorphological diversification in lowland freshwater fish assemblages from five biotic regions. Ecological Monographs 61(4):343-365.

Wootton, R. J. 1998. The Ecology of Teleost Fishes, 2 ed. Dordrecht, Kluwer Academic Publisher. 386p. 